\title{
A new method for estimating the leaf area index of cucumber and tomato plants
}

\author{
Flávio Favaro Blanco; Marcos Vinícius Folegatti \\ ESALQ/USP, Av. Pádua Dias, 11, C. Postal 09, 13418-900 Piracicaba-SP; E-mail: ffblanco@carpa.ciagri.usp.br
}

\begin{abstract}
Non-destructive methods of leaf area measurement are useful for small plant populations, such as experiments with potted plants, and allow the measurement of the same plant several times during the growing period. A methodology was developed to estimate the leaf area index (LAI) of cucumber and tomato plants through the evaluation of the leaf area distribution pattern (LADP) of the plants and the relative height of the leaves in the plants. Plant and leaf height, as well as the length and width of all leaves were measured and the area of some leaves was determined by a digital area meter. The obtained regression equations were used to estimate the leaf area for all relative heights along the plant. The LADP adjusted to a quadratic model for both crops and LAI were estimated by measuring the length and width of the leaves located at the relative heights representing the mean leaf area of the plants. The LAI estimations presented high precision and accuracy when the proposed methodology was used resulting in time and effort savings and being useful for both crops.
\end{abstract}

Keywords: Cucumis sativus L., Lycopersicon esculentum Mill., greenhouse, leaf area index.

\section{RESUMO}

Um novo método para estimar o índice de área foliar de plantas de pepino e tomate

Métodos não destrutivos para a medição da área foliar são úteis para pequena população de plantas, como experimentos com plantas conduzidas em vasos, e permitem que a mesma planta seja medida várias vezes durante o período de cultivo. O objetivo desse trabalho foi desenvolver uma metodologia para a estimativa do índice de área foliar (IAF) do pepino e do tomate pela determinação do padrão de distribuição de área foliar (PDAF) das plantas e da altura relativa da folha que representa a área foliar média da planta. A altura da planta e da folha, assim como o comprimento e a largura de todas as folhas, foram medidos e algumas folhas tiveram sua área determinada por um medidor digital de área foliar. As equações de regressão obtidas foram utilizadas para estimar a área foliar para todas as alturas relativas ao longo da planta. O PDAF ajustou-se a um modelo quadrático para ambas as culturas e o IAF foi estimado através de medidas do comprimento e da largura das folhas localizadas nas alturas relativas que representavam a área foliar média das plantas. As estimativas do IAF pela metodologia proposta apresentaram alta precisão e exatidão, sendo que a metodologia promove economia de tempo e esforço na determinação do IAF e pode ser utilizada com sucesso para ambas as culturas.

Palavras-chave: Cucumis sativus L., Lycopersicon esculentum Mill., ambiente protegido, índice de área foliar.

(Recebido para publicação em 4 de dezembro de 2002 e aceito em 4 de julho de 2003)

$\mathrm{L}$ eaf is an important plant organ, and is associated with photosynthesis and evapotranspiration; therefore, leaf area measurements are required in most physiological and agronomic studies involving plant growth (Guo \& Sun, 2001). Many methods of leaf area measurements have been developed. Direct methods for determining leaf area are restricted to the use of an automatic area-integrating meter. Tracing, shadowgraphing or the use of a planimeter to measure the leaf area of leaves attached to shoots is time consuming and tedious; also, in some experiments time is insufficient to make such measurements (Manivel \& Weaver, 1974). Estimation of leaf area from mathematical models involving linear measurements of leaves is relatively accurate and non-destructive.
A mathematical model can be obtained by correlating the leaf length (L), width (W) or length $\mathrm{x}$ width (LW) to the actual leaf area (LA) of a sample of leaves using regression analysis. The non-destructive methods based on linear measurements are quicker and easier to be executed and present good precision for the study of plant growth in several crops (Manivel \& Weaver, 1974; Sepaskhah, 1977; Strik \& Proctor, 1985; Pedro Júnior et al., 1986; Robbins \& Pharr, 1987; Silva et al., 1998; Gutiérrez \& Lavín, 2000; Astegiano et al., 2001; Guo \& Sun, 2001).

Cucumber and tomato are some of the main crops cultivated in greenhouse in Brazil and researches with these crops are essential to establish the best management practices to increase yield and fruit quality. Researches with plants cultivated in pots are common under greenhouse conditions because less space is required and the number of treatments and replications can be quite increased. Under pot cultivation, a nondestructive method for LAI evaluation is required with the advantage that the same plant can be measured several times during the growing period, thus leading to a more real curve of LAI increase along the growing season.

A non-destructive methodology for estimating the LAI for greenhousegrowing tomato and cucumber plants, based on linear measurement models was developed in this study.

\section{MATERIAL AND METHODS}

In the first cucumber season, a greenhouse of $1.6 \mathrm{~m}$ height of lateral 
Table 1. Relationships between leaf length (L), width (W), LxW, and total leaf area for cucumber and tomato in each season. Piracicaba, ESALQ/USP, 1999/2001.

\begin{tabular}{|c|c|c|c|}
\hline Crop & Season & Regression equation & $\mathbf{R}^{\mathbf{2}}$ \\
\hline \multirow{2}{*}{ Cucumber } & First & $\begin{array}{l}\mathrm{LA}=38.153 . \mathrm{L}-333 \\
\mathrm{LA}=38.2 . \mathrm{W}-503 \\
\mathrm{LA}=0.859 .(\mathrm{L} . \mathrm{W})+2.7\end{array}$ & $\begin{array}{l}0.91 \\
0.94 \\
0.95\end{array}$ \\
\hline & Second & $\begin{array}{l}\mathrm{LA}=1.16 . \mathrm{L}^{2}-3.1 . \mathrm{L}+11.6 \\
\mathrm{LA}=0.36 \cdot \mathrm{W}^{2}+11.92 . \mathrm{W}-88 \\
\mathrm{LA}=0.851 .(\mathrm{L} . \mathrm{W})\end{array}$ & $\begin{array}{l}0.99 \\
0.99 \\
0.99 \\
\end{array}$ \\
\hline Tomato & First & $\begin{array}{l}\mathrm{LA}=0.35 . \mathrm{L} 2-5.31 . \mathrm{L}+57.6 \\
\mathrm{LA}=0.708 . \mathrm{W}^{2}-10.44 . \mathrm{W}+83.4 \\
\mathrm{LA}=0.347 .(\mathrm{L} . \mathrm{W})-10.7\end{array}$ & $\begin{array}{l}0.95 \\
0.98 \\
0.98\end{array}$ \\
\hline
\end{tabular}

opening, $10 \mathrm{~m}$ wide and $20 \mathrm{~m}$ long and covered with a polyethylene film of 0.15 $\mathrm{mm}$ thickness was used. The lateral curtains were closed at night and opened during the day greenhouse was located in a experimental area of the Universidade de São Paulo, Piracicaba city, Brazil. Cucumber seedlings, cv. Hokushin, were transplanted on $13^{\text {th }}$ January, 1999, in four beds, each one with two rows of plants, giving a plant population of 2.5 plants $\mathrm{m}^{-2}$. Plants were trained with a single stem along and around a vertical plastic string. Water was applied by a drip irrigation system, with one dripper per plant, and fertilizers containing $\mathrm{N}, \mathrm{P}, \mathrm{K}, \mathrm{Ca}, \mathrm{Mg}$ and $\mathrm{S}$ were applied with the irrigation water in all irrigations, following the uptake rate of cucumber in greenhouse (Papadopoulos, 1994).

Forty days after transplanting (DAT), five plants were selected and the width (W) and length (L) of all leaves were measured with a simple ruler. In addition, plant height and the insertion height of the petiole from each leaf was also obtained to calculate the relative leaf height by the equation:

$$
\mathrm{RLH}=\frac{\mathrm{LH}}{\mathrm{PH}}
$$

where RLH is the relative leaf height, LH is the leaf height (m), that is, the distance between the soil surface and the node corresponding to the leaf, and $\mathrm{PH}$ the plant height $(\mathrm{m})$. In the same day, leaves of different sizes were selected to represent the full spectrum of measurable leaf sizes and their areas were measured using a LI-COR 3000 leaf area meter. Length was measured from lamina tip to the point of intersection of the lamina and petiole and width were measured from tip to tip between the widest lamina lobes (Figure 1A). The relative leaf area (RLA) was calculated by dividing the area of each leaf by the mean leaf area of the plant for each RLH as follows:

$$
\mathrm{RLA}=\frac{\mathrm{LA}}{\mathrm{LA}_{u}}
$$

where RLA is the relative leaf area, LA is the leaf area of a given leaf $\left(\mathrm{cm}^{2}\right)$ and $\mathrm{LA}_{\mathrm{M}}$ is the mean leaf area of the plant $\left(\mathrm{cm}^{2}\right.$ leaf $\left.{ }^{-1}\right)$ given by the sum of the LA of all leaves divided by the number of leaves of each plant. The RLH was plotted against RLA in order to determine the leaf whose area represents the mean leaf area of the plant.

In the second season, cucumber seedlings were grafted on squash (Cucurbita spp.), hybrid Excite-Ikki, and cultivated in a greenhouse in the experimental area of the Universidade de São Paulo. The greenhouse was 6.3 $\mathrm{m}$ wide, $17.5 \mathrm{~m}$ long and the lateral opening was $2.8 \mathrm{~m}$ height, with polyethylene cover of $0.15 \mathrm{~m}$ thickness. The management of the lateral curtains and the plants spacing, training, irrigation and fertilization was the same as the first season. Seedlings were transplanted on $23^{\text {th }}$ June, 1999, and the leaf measurements were performed at 35 and 54 DAT.

Tomato, hybrid Facundo, grew in a $22.5 \mathrm{~m}$ length, $6.4 \mathrm{~m}$ wide and $3 \mathrm{~m}$ height greenhouse covered with polyethylene film, of $0.15 \mathrm{~mm}$ thickness located in the same area used for the second cucumber season. The laterals did not have curtains but an anti-aphid screen to avoid the action of vectors of viral diseases. Plants were transplanted on $23^{\text {th }}$ October, 2001, on pots containing about $60 \mathrm{~kg}$ of dry soil and were conducted with a single stem. Drip irrigation frequency and amount was controlled by tensiometers installed at 0.15 and $0.30 \mathrm{~m}$ depth, $0.10 \mathrm{~m}$ from the plant. Preplant fertilization was done based on soil fertility analysis. Fertigation with N, K and Ca followed the nutrient uptake rate of tomato (Fayad, 1998). Plants were spaced at 1 $\mathrm{x} 0.5 \mathrm{~m}$ with one plant per pot and leaf measurements were taken at 30 and 42 DAT following the same criteria used for the measurements of the cucumber leaves (Figure 1B).

To evaluate the performance of the methodology, the $\mathrm{L}$ and $\mathrm{W}$ of all leaves of five plants different from those used in the model development, from each crop and season were measured and, the areas of the leaves located at the relative heights that represented the $\mathrm{LA}_{\mathrm{M}}$ were used to calculate the LAI by the equation:

$$
\mathrm{LAI}=\frac{\mathrm{LA}_{\mathrm{M}} \cdot \mathrm{N}}{\mathrm{A}}
$$

where $\mathrm{N}$ is the number of leaves in the plant and $\mathrm{A}$ the area $\left(\mathrm{cm}^{2}\right)$ occupied by one plant in the cropped area. Estimated LAI was correlated to the measured LAI, the sum of the areas of 


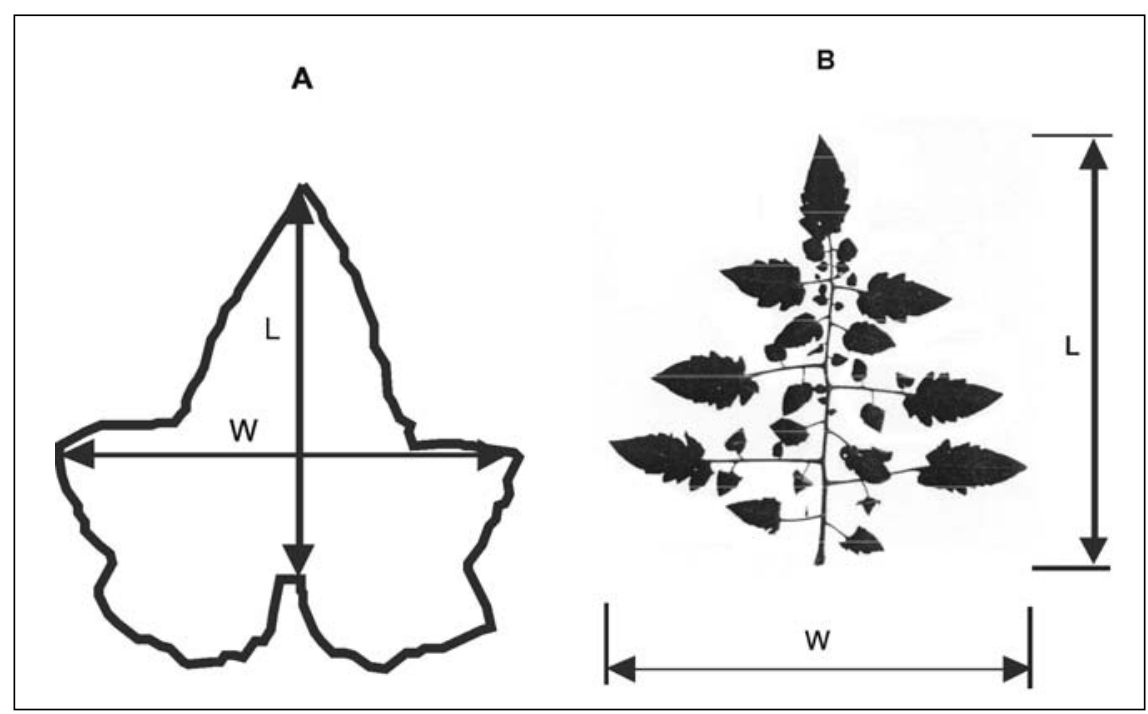

Figure 1. Diagram of cucumber (A) and tomato (B) leaf showing positions of length (L) and width (W) measurements. Piracicaba, ESALQ/USP, 1999/2001.

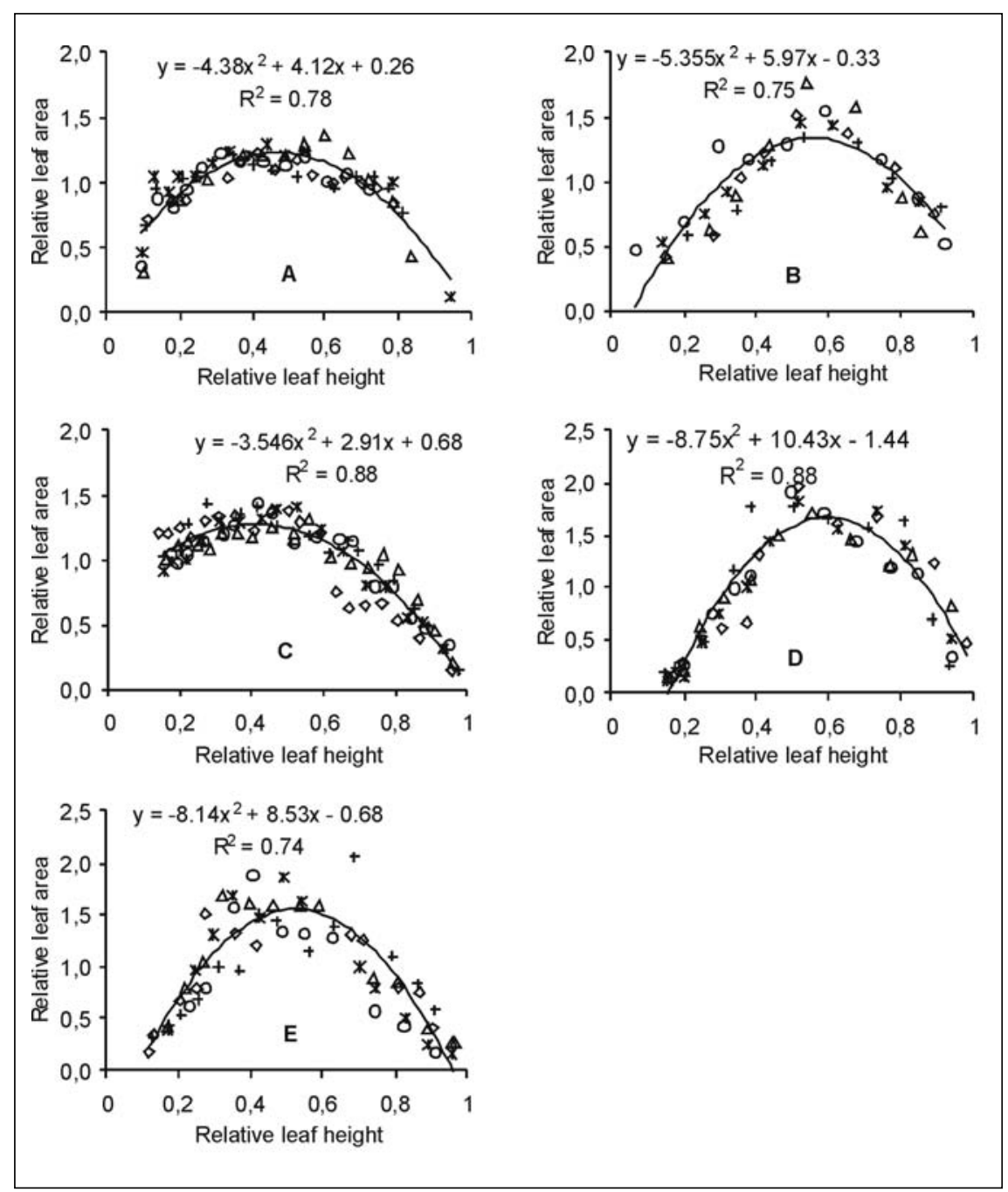

Figure 2. Leaf area distribution pattern for the five plants measured of: (A) Non-grafted cucumber; (B) Grafted cucumber, 35 DAT; (C) Grafted cucumber, 54 DAT; (D) Tomato, 30 DAT and (E) Tomato, 42 DAT. Each symbol corresponds to each of the five plants measured. Piracicaba, ESALQ/USP, 1999/2001. all leaves divided by A, and the results were plotted and analysed by means of the regression slope, coefficient of determination $\left(\mathrm{r}^{2}\right)$ and coefficient of Willmott (Willmott, 1981).

\section{RESULTS AND DISCUSSION}

The equations relating the leaf area with the L, W and LxW for all crops are shown in Table 1. Equations that use only $\mathrm{L}$ or $\mathrm{W}$ showed good relationships with LA, which demand less effort and time in the measurement at field because just one dimension could be measured. The equation used to estimate LA, to determine leaf area distribution pattern (LADP) of the plants was that showed the highest $r^{2}$ value.

The LADP for each crop and season is shown in Figure 2. A high correlation can be observed between the RLA and RLH, which adjusted to a quadratic model for both crops. The RLA increases from the bottom of the plant and reaches the maximum value at RLH of about 0.5 , when it decreases again until reaching the plant apex. For the measurement of grafted cucumber at 54 DAT there was no leaf bellow the RLH of 0.15 because the pruning of the old leaves accomplished few days before the plants measurement.

From the adjusted equations, it was possible to calculate the relative height of the leaf that represented the $\mathrm{LA}_{\mathrm{M}}$ of the plant for each crop. The leaves that represented the $\mathrm{LA}_{\mathrm{M}}$ were that corresponding to a RLH of 0.24 and 0.70 for non-grafted cucumber, 0.31 and 0.81 for grafted cucumber at 35 DAT, 0.13 and 0.69 for grafted cucumber at 54 DAT, 0.32 and 0.87 for tomato at 30 DAT and 0.27 and 0.78 for tomato at 42 DAT. In a general way, the RLH that represented $\mathrm{LA}_{\mathrm{M}}$ decreased along the growing period for grafted cucumber and tomato, indicating that the LADP should be determined before every LAI measurement.

Thus, as advocated in the present study, it is possible to have a good estimate of LAI simply by measuring the width and length of the leaf located at the RLH that represents the mean leaf area of the plant. Figure 3 shows the results of the test of the methodology 
performance for estimating LAI. The estimated values of LAI were very close to the measured values, giving an overestimation of $1.7 \%$ in the predictions. The coefficient $r^{2}$ indicated that the estimations had a precision of $98 \%$ and the coefficient of Willmott (d) indicated an accuracy of $99.6 \%$. These coefficients were sufficiently high and the prediction of the LAI by the proposed method could be satisfactory for most purposes and experiments where the LAI determination is needed.

This study has shown that leaf area estimations based on linear measurements in situ are reliable. The approach used here is rapid, inexpensive, simple and precise for LAI determination in crops growing in greenhouse. Some sacrifice in accuracy is inevitable, but using larger populations in the experiments may reduce the deviations.

\section{ACKNOWLEDGEMENTS}

To Fundação de Amparo à Pesquisa no Estado de São Paulo, FAPESP, for the financial support.

\section{CITED LITERATURE}

ASTEGIANO, E.D.; FAVARO, J.C.; BOUZO, C.A. Estimación del area foliar en distintos cultivares de tomate (Lycopersicon esculentum Mill.) utilizando medidas foliares lineales. Investigación Agraria: Producción y Protección Vegetales, v. 16, n. 2, p. 249-256, 2001.

FAYAD, J.A. Absorção de nutrientes, crescimento e produção do tomateiro cultivado em condições de campo e estufa. Viçosa: UFV, $1998.81 \mathrm{p}$ (Tese mestrado)

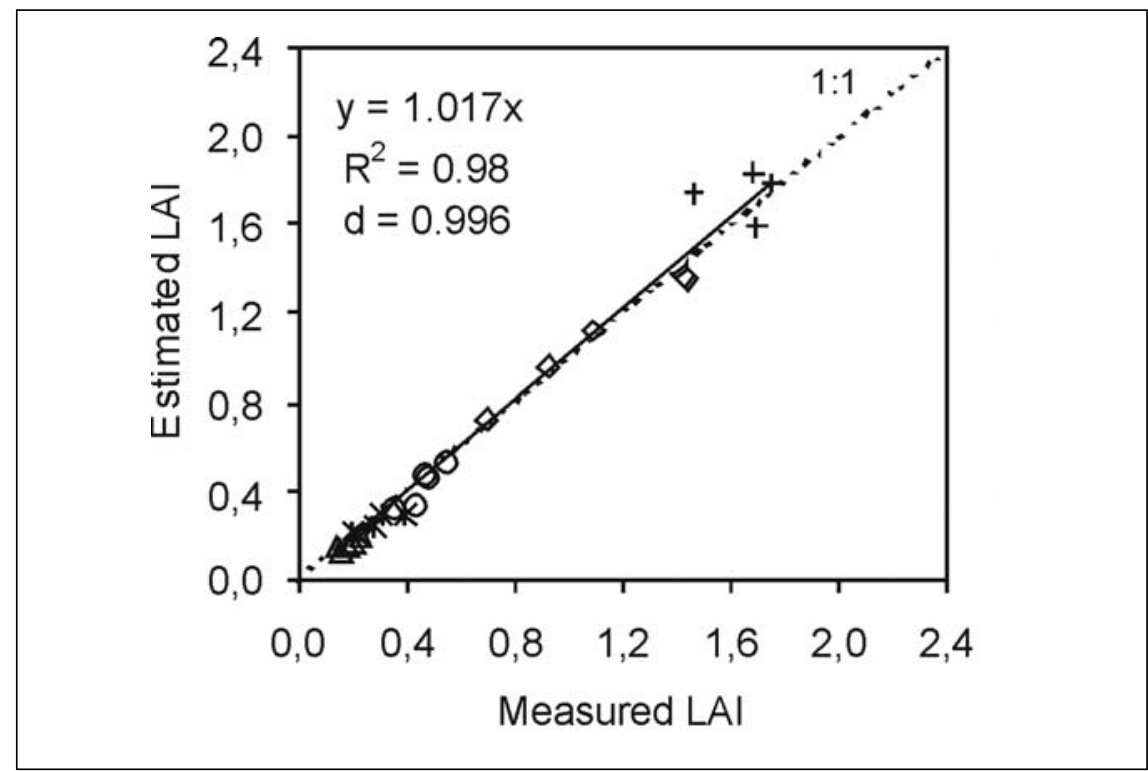

Figure 3. Estimated and measured leaf area index (LAI) for five plants of each crop (tomato and cucumber), season and time of measurement. Each symbol corresponds to each of the five plants measured. Piracicaba, ESALQ/USP, 1999/2001.

GUO, D.P.; SUN, Y.Z. Estimation of leaf area of stem lettuce (Lactuca sativa var angustana) from linear measurements. Indian Journal of Agricultural Sciences, v. 71, n. 7, p. 483-486, 2001. GUTIÉRREZ T.A.; LAVÍN A.A. Mediciones lineales en la hoja para la estimación no destructiva del área foliar en vides cv. Chardonnay. Agricultura Técnica, v. 60, n. 1, p. 69-73, 2000.

MANIVEL, L.; WEAVER, R.J. Biometric correlations between leaf area and length measurements of 'Grenache' grape leaves. HortScience, v. 9, n. 1, p. 27-28, 1974.

PAPADOPOULOS, A.P. Growing greenhouse seedless cucumbers in soil and in soilless media. 1994. 126p. (Agriculture and Agri-Food Canada Publication, 1902/E)

PEDRO JÚNIOR, M.J.; RIBEIRO, I.J.A.; MARTINS, F.P. Determinação da área foliar em videira cultivar Niágara Rosada. Bragantia, v. 45, n. 1, p. 199-204, 1986.
ROBBINS, N.S.; PHARR, D.M. Leaf area prediction models for cucumber from linear measurements. HortScience, v. 22, n. 6, p. 12641266, 1987.

SEPASKHAH, A.R. Estimation of individual and total leaf areas of safflowers. Agronomy Journal, v. 69, n. 5, p. 783-785, 1977.

SILVA, N.F.; FERREIRA, F.A.; FONTES, P.C.R.; CARDOSO, A.A. Modelos para estimar a área foliar de abóbora por meio de medidas lineares. Revista Ceres, v. 45, n. 259, p. 287-291, 1998.

STRIK, B.C.; PROCTOR, J.T.A. Estimating the area of trifoliolate and unequally imparipinnate leaves of strawberry. HortScience, v. 20, n. 6, p. 1072-1074, 1985.

WILLMOTT, C.J. On the validation of models. Physical Geography, v. 2, n. 2, p. 184-194, 1981. 